\title{
KEDUDUKAN GADAI SYARIAH (RAHN) DALAM SISTEM HUKUM JAMINAN INDONESIA
}

\author{
Budiman Setyo Haryanto \\ Fakultas Hukum Universitas Jenderal Soedirman, Purwokerto, Jawa Tengah \\ e-mail: budimanharyanto@rocketmail.com
}

\begin{abstract}
Rahn according to Islamic Law is a guarantee institution used in Syariah Bank. Based on the existence, Rahn legal construction has similar traits to the legal construction of pand (Gadai) according to Civil Code. Those traits are consisting of an accessory transaction for the main transaction as a monetary transaction, an moveable object for its guarantee, a principle of inbezitstelling, a preferent creditor for payment for its debt. Therefore, all regulations for pand (gadai) can be applied to Rahn with analogical interpretation.
\end{abstract}

Keywords : Rahn, pand, Islamic Law

\begin{abstract}
Abstrak
Gadai Syariah menurut Hukum Islam adalah sebuah institusi garansi yang digunakan dalam Bank syariah. Berdasarakan eksistensinya, konstruksi hubungan hukum Rahn (Gadai Syariah) identik (persamaan dalam unsur) dengan konstruksi hubungan hukum gadai (pand) menurut KUH. Perdata, yaitu sebagai perjanjian ikutan (accessoir) terhadap perjanjian pokok yang pada umumnya berupa perjanjian peminjaman sejumlah uang, obyeknya berupa benda bergerak dan benda tersebut harus dikeluarkan dari kekuasaan debitur (asas inbezitstelling), dan memberikan hak kepada kreditur untuk mengambil pelunasan lebih dahulu atas hasil eksekusi benda yang secara khusus diperikatkan. Oleh karenanya, seluruh ketentuan dalam gadai (pand) dapat diterapkan dalam Rahn dengan penerapan secara analogi.
\end{abstract}

Kata Kunci : Gadai syariah, gadai, Hukum Islam

\section{Pendahuluan}

Pembangunan ekonomi sebagai bagian dari Pembangunan Nasional bertujuan untuk menciptakan masyarakat Indonesia yang adil dan makmur berdasar Pancasila dan UndangUndang Dasar 1945. Dalam rangka pembangunan ekonomi Indonesia, bidang hukum yang meminta perhatian secara serius dalam pembinaan hukumnya di antaranya ialah lembaga jaminan. Pembinaan hukum dalam bidang Hukum Jaminan adalah sebagai konsekuensi logis dan merupakan perwujudan tanggung jawab pembinaan hukum guna mengimbangi lajunya kegiatan-kegiatan dalam bidang perdagangan, perindustrian, perseroan, pengangkutan maupun kegiatan-kegiatan dalam proyek pembangunan. Kegiatan-kegiatan tersebut yang pada akhirnya memerlukan adanya fasilitas kredit dalam usahanya dan di pihak lain pem- beri modal mensyaratkan adanya jaminan bagi pemberian kredit demi keamanan modal dan kepastian hukumnya. ${ }^{1}$

Pinjam-meminjam termasuk perbuatan hukum yang mengandung resiko, di mana debitur tidak melakukan kewajiban prestasinya, atau yang sering disebut dengan kredit macet. Oleh karena itu diperlukan adanya perlindungan hukum untuk melindungi piutang seorang kreditur terhadap debiturnya. Perlindungan tersebut meliputi adanya jaminan kepastian hukum akan hak-haknya, dan adanya sarana yang mudah dan cepat untuk melakukan eksekusi atas kekayaan debitur. Hal-hal inilah yang menjadi obyek pengaturan Hukum Jaminan.

Purwahid Patrik, Kashadi, 1998, Hukum Jaminan, Edisi Revisi Dengan UUHT, Semarang: Fakultas Hukum Universitas Diponegoro, hlm. 2-3. 
J. Satrio memberikan perumusan hukum jaminan sebagai peraturan hukum yang mengatur tentang jaminan piutang seorang kreditur terhadap debiturnya. ${ }^{2}$ Hal ini berarti bahwa yang diatur dalam hukum jaminan adalah mengenai upaya memberikan perlindungan hukum (jaminan) kepada kreditur dalam mempertahankan dan melaksanakan haknya guna mendapatkan pelunasan piutangnya dari seorang debitur.

Soedewi menyebut bahwa bentuk lembaga jaminan sebagian besar mempunyai ciriciri internasional, dikenal hampir di semua Negara dan dalam perundang-undangan modern, bersifat menunjang perkembangan ekonomi dan perkreditan, serta memenuhi kebutuhan masyarakat akan fasilitas modal. Djoko Muljadi menyebutkan bahwa peran serta lembaga jaminan di dalam pembangunan ekonomi suatu negara sangat penting, maka Hukum Jaminan tergolong bidang hukum yang akhir-akhir ini secara popular disebut Hukum Ekonomi (The Economic Law), Wiertshaftrecht atau Droit de Economique yang mempunyai fungsi memajukan ekonomi. Sehingga bidang hukum demikian pengaturannya dalam undang-undang perlu diprioritaskan. ${ }^{3}$ Adapun bentuk-bentuk lembaga jaminan tersebut antara lain adalah Gadai, Fidusia, Hipotek, Borgtocht dan sebagainya.

Subekti menyebutkan bahwa lembaga jaminan mempunyai tugas melancarkan dan mengamankan pemberian kredit, maka jaminan yang baik (ideal) adalah Pertama, yang dapat secara mudah membantu perolehan kredit itu oleh pihak yang memerlukannya; Kedua, yang tidak melemahkan potensi (kekuatan) si pencari kredit untuk melakukan (meneruskan) usahanya; Ketiga, yang memberikan kepastian kepada si pemberi kredit, dalam arti bahwa barang jaminan setiap waktu tersedia untuk dieksekusi, yaitu bila perlu dapat mudah di-

J. Satrio, 1991, Hukum Jaminan, Hak-hak Jaminan Kebendaan, Bandung: PT. Citra Aditya Bhakti, hlm. 3.

Djoko Muljadi, 1972, Pengaruh Penanaman Modal Asing Atas Perkembangan Hukum Persekutuan Perseroan Dagang (Vennootschapsrecht) Dewasa Ini, Majalah Hukum dan Masyarakat. uangkan untuk melunasi utangnya si penerima kredit. ${ }^{4}$

Munir Fuady menyebutkan bahwa pada prinsipnya campur tangan sektor yuridis untuk mengatur masalah perkreditan adalah untuk memenuhi unsur safety, soundness, dan without substantial risk; perlindungan yang seimbang antara nasabah dan bank; dan, menjamin berjalannya kompetisi dan efisiensi. ${ }^{5}$

Dewasa ini banyak bermunculan Bank Islam atau Bank Syariah di Indonesia sebagai salah satu alternatif pemecahan masalah keuangan atau permodalan, khususnya bagi masyarakat muslim Indonesia dan masyarakat Indonesia pada umumnya. Bank Syariah di Indonesia sebagai lembaga keuangan Islam dilengkapi dengan lembaga pendukung yang juga beroperasi secara Islami, seperti Badan Arbitrase Muamalah Indonesia (BAMUI) yang bertugas untuk menyelesaikan sengketa muamalah yang dihadapi oleh orang-orang Islam, dan Asuransi Tafakul yang aktivitasnya berdasarkan pada prinsip-prinsip Islam.

Menyusul kemudian muncul lembaga jaminan syariah yang dinamakan Rahn. Kata "Rahn" menurut bahasa berarti tetap, berlangsung dan menahan. Menurut istilah, Rahn berarti menjadikan sesuatu benda bernilai menurut syara' sebagai jaminan utang; dengan adanya benda yang menjadi tanggungan ini seluruh atau sebagian utang dapat diberikan. ${ }^{6}$

Mencermati hal tersebut, permasalahan yang menarik untuk dibahas adalah mengenai konstruksi hukum Rahn dihubungkan dengan gadai (pand) dalam KUH. Perdata dan bagaimanakah kedudukan Rahn dalam sistem hukum jaminan Indonesia?

\section{Pembahasan}

Subekti, 1989, Jaminan-Jaminan Untuk Pemberian Kredit Menurut Hukum Indonesia, Bandung: PT. Citra Aditya Bhakti, hlm. 19.

5 Munir Fuady, 2002, Hukum Perkreditan Kontemporer, Bandung: PT. Citra Aditya Bhakti, hlm. 2.

$6 \quad$ Warkum Sumitro, 2004, Asas-asas Perbankan Islam dan Lembaga-lembaga Terkait, Bamui, Tafakul dan Pasar Modal Syariah di Indonesia, Jakarta: PT. Radja Grafindo Persada, hlm 3. 
Konstruksi Hubungan Hukum Rahn dihubungkan dengan Gadai (pand) menurut KUH. Perdata.

Sejak tahun 2002 atas dasar Fatwa Dewan Syariah Nasional Nomor 25/DSN-MUI/III/2002, tertanggal 26 Juni 2002 dinyatakan bahwa pinjaman dengan menggunakan barang sebagai jaminan dalam bentuk Gadai Syariah (Rahn) diperbolehkan, yaitu suatu bentuk penyerahan harta milik si peminjam sebagai jaminan atas pinjaman yang diterimanya. Rahn dikembangkan melalui Bank Syariah dan lembaga keuangan bukan bank yaitu Pegadaian Syariah.

Heri Sudarsono mengatakan bahwa, "Gadai dalam fiqh disebut rahn, yang menurut bahasa adalah nama barang yang dijadikan sebagai jaminan kepercayaan. Sedangkan menurut syara' artinya menyandera sejumlah harta yang diserahkan sebagai jaminan secara hak, tetapi dapat diambil kembali sebagai tebusan. ${ }^{7}$ Selanjutnya Azhar Basyir menyebutkan "Rahn berarti tetap, berlangsung dan menahan sesuatu barang sebagaimana tanggungan utang. Rahn berarti menjadikan sesuatu benda bernilai menurut syara' sebagai jaminan hutang; dengan adanya benda yang menjadi tanggungan ini seluruh atau sebagian hutang dapat diberikan". 8

Berdasarkan uraian di atas dapat diketahui materi pokok dari Rahn, yaitu : 1) merupakan lembaga jaminan, 2) obyeknya adalah benda yang mempunyai nilai ekonomis, 3) dilakukan dengan penyerahan benda kepada kreditur, 4) kreditur berhak menahan benda dan menjual serta mengambil pelunasan dari hasil penjualan apabila debitur wanprestasi, 5) utang yang dijamin adalah hutang tanpa bunga (riba). ${ }^{9}$

Apabila dihubungkan antara konstruksi hukum gadai dalam KUH. Perdata dengan kons-

Heri Sudarsono, 2003, Bank dan Lembaga Keuangan Syariah, Diskripsi dan Ilustrasi, Ekonsia, Yogyakarta: Fakultas Ekonomi UII, hlm. 141.

8 Loc.Cit

9 Adapun yang dinamakan riba adalah penambahan, perkembangan, peningkatan dan pembesaran yang diterima pemberi pinjaman dari peminjam dari jumlah pinjaman pokok sebagai imbalan karena menangguhkan atau berpisah dari sebagian modalnya selama periode tertentu truksi hukum Rahn, maka akan dijumpai perbedaan di antara keduanya sebaimana tampak pada tabel 1 .

Dengan diterapkannya Rahn oleh Bank Syariah maupun Pegadaian Syariah, membawa konsekuensi hukum bahwa sekarang di Indonesia dikenal ada tiga jenis transaksi gadai, yaitu Pertama, Gadai (Pand) menurut KUH. Perdata yang digunakan sebagai jaminan dalam kegiatan usaha Bank Konvensional; Kedua, Gadai (Verpanding) menurut Aturan Dasar Pegadaian/ADP (Pandhuis Reglement) sebagai kegiatan usaha pokok pada Perum Pegadaian; Ketiga, Gadai Syariah (Rahn) sebagai jaminan peminjaman uang pada kegiatan usaha Bank Syariah dan Pegadaian Syariah.

Dari ketiga jenis gadai tersebut, dua yang pertama yaitu Gadai (Pand) dan Gadai pada Perum Pegadaian sudah diatur dalam peraturan perundang-undangan, sedangkan Rahn belum diatur dalam peraturan perundang-undangan.

Belum adanya peraturan perundang-un-dangan yang mengatur mengenai Rahn sebagai pola hubungan hukum baru di bidang transaksi jaminan, menimbulkan keadaan vacuum atau kekosongan hukum di bidang gadai syariah. Menurut IImu Pengetahuan Hukum, untuk mengisi kekosongan hukum diperlukan alat bantu berupa konstruksi hukum yaitu tindakan analisis kritis untuk memahami suatu pola hubungan hukum sehingga dapat ditentukan bangunan hukumnya. $^{10}$

Berdasarkan tabel 1, dapat dinyatakan bahwa pada 24dasarnya konstruksi hukum gadai syariah (Rahn) adalah identik dengan gadai (pand) menurut KUH. Perdata, yaitu: samasama memandang perjanjian gadai sebagai per-

10 konstruksi hukum dibutuhkan khususnya untuk memahami suatu hubungan hukum baru yang belum ada aturan hukum yang secara khusus mengaturnya, sehingga dapat ditentukan aturan hukumnya. Caranya adalah dengan menerapkan salah satu ketentuan hukum atau berbagai aturan hukum secara bersamaan atau model campuran. Kegiatan yang harus dilakukan adalah menyelidiki apa yang esensial dari suatu hubungan hukum itu, di antaranya dengan melakukan abstraksi, dan membuang semua bentuk kekhususannya dan pada akhirnya dapat ditentukan esensinya. Dengan demikian yang dinamakan konstruksi hukum adalah suatu tindakan analitis kritis untuk memahami suatu pola hubungan hukum sehingga dapat ditentukan bangunan hukumnya (Paul Scholten). 
Tabel 1

Perbandingan Gadai (Pand) dan Gadai Syariah (Rahn)

\begin{tabular}{|c|c|c|}
\hline & Gadai (Pand) & Gadai Syariah (Rahn \\
\hline Pengertian & $\begin{array}{l}\text { Hak kreditur untuk mengambil pelunasan atas } \\
\text { benda jaminan }\end{array}$ & $\begin{array}{l}\text { Hak kreditur untuk mengambil pelunasan atas benda } \\
\text { jaminan }\end{array}$ \\
\hline Pemberi Gadai & Debitur atau pihak III & Debitur \\
\hline $\begin{array}{l}\text { Penerima } \\
\text { Gadai }\end{array}$ & Orang perseorangan, Bank & Orang perseorangan, Bank \\
\hline Obyek Gadai & Benda bergerak bertubuh dan tidak bertubuh & $\begin{array}{l}\text { Benda yang mempunyai nilai ekonomis, dapat } \\
\text { dimanfaatkan dan dapat dikualifikasi }\end{array}$ \\
\hline $\begin{array}{l}\text { Hutang yang } \\
\text { dijamin }\end{array}$ & Hutang dari semua jenis perikatan & Pinjam-meminjam uang tanpa bunga \\
\hline $\begin{array}{l}\text { Hak Penerima } \\
\text { Gadai }\end{array}$ & $\begin{array}{l}\text { 1. Parate eksekusi (hak menjual benda gadai } \\
\text { atas kekuasaan sendiri) } \\
\text { 2. hak revindikasi dan hak-hak kebendaan } \\
\text { lainnya } \\
\text { 3. hak retensi } \\
\text { 4. hak mengambil pelunasan lebih dahulu } \\
\text { 5. dibebaskan dari tuntutan hukum yang } \\
\text { berkaitan dengan benda gadai }\end{array}$ & $\begin{array}{l}\text { 1. hak menguasai benda gadai sampai hutang dilunasi } \\
\text { 2. hak menjual untuk mengambil pelunasan }\end{array}$ \\
\hline $\begin{array}{l}\text { Kewajiban } \\
\text { Penerima } \\
\text { Gadai }\end{array}$ & $\begin{array}{l}\text { 1. memberi tahu debitur kalau melakukan } \\
\text { eksekusi } \\
\text { 2. memelihara benda gadai dan menanggung } \\
\text { kerusakan karena salahnya } \\
\text { 3. mengembalikan uang sisa hasil eksekusi } \\
\text { 4. berhak menerima bunga dari piutang yang } \\
\text { digadaikan }\end{array}$ & $\begin{array}{l}\text { 1. memelihara dan menyimpan benda gadai } \\
\text { 2. memberi tahu debitur agar segera melunasi } \\
\text { hutangnya } \\
\text { 3. mengembalikan uang sisa eksekusi }\end{array}$ \\
\hline $\begin{array}{l}\text { Hak Pemberi } \\
\text { Gadai }\end{array}$ & $\begin{array}{l}\text { 1. menerima pengembalian uang sisa eksekusi } \\
\text { 2. meminta pengembalian benda gadai kalau } \\
\text { disalahgunakan } \\
\text { 3. menerima ganti rugi kalau benda gadai } \\
\text { hilang/rusak }\end{array}$ & $\begin{array}{l}\text { 1. menerima pengembalian uang sisa eksekusi } \\
\text { 2. menerima ganti rugi kalau benda gadai hilang/rusak }\end{array}$ \\
\hline $\begin{array}{c}\text { Kewajiban } \\
\text { Pemberi Gadai }\end{array}$ & $\begin{array}{l}\text { Menjamin bahwa benda gadai adalah milik } \\
\text { pemberi gadai }\end{array}$ & $\begin{array}{l}\text { 1. membayar biaya pemeliharaan dan penyimpanan } \\
\text { 2. menjamin bahwa benda gadai adalah milik pemberi } \\
\text { gadai }\end{array}$ \\
\hline
\end{tabular}

perjanjian ikutan (accessoir) dari perjanjian pokok yang dijamin, obyek gadai adalah benda bergerak, benda gadai dikeluarkan dari kekuasaan pemberi gadai, hak utama kreditur penerima gadai adalah menjual benda gadai (eksekusi) dalam hal debitur wanprestasi untuk mengambil pelunasan dengan kewajiban mengembalikan uang sisa hasil penjualan (eksekusi).

Akan tetapi di samping persamaan-persamaan sebagaimana tersebut di atas, terdapat perbedaan yang hakiki, yaitu: pada Rahn debitur pemberi gadai wajib membayar biaya penyimpanan dan pemeliharaan, sedangkan pada gadai (Pand) tidak demikian halnya. Argumentasi dari adanya kewajiban bagi debitur pemberi gadai untuk membayar biaya pemeliharaan dan penyimpanan adalah didasarkan pada karakter pemberian pinjaman uang yang dijamin dengan Rahn tersebut, sehingga bagi kreditur penerima gadai diberikan kesempatan untuk mendapatkan tambahan dari pokok pinjaman dengan cara menentukan prosentase tambahan dari pokok hutang yang diperhitungkan setiap bulan sebagai pungutan biaya pemeliharaan dan penyimpanan benda jaminan.

Di luar perbedaan pokok tersebut, pengaturan gadai (pand) dalam KUH. Perdata meliputi Pertama, pemberi gadai boleh pihak ketiga, sehingga hal ini memungkinkan orang dapat menggadaikan barangnya untuk hutang orang lain atau dibalik, orang dapat mempunyai hutang dengan jaminan gadai barangnya orang lain (Pasal 1150 KUH. Perdata); Kedua, benda gadai meliputi benda bergerak tidak bertubuh atau suatu hak tagih, yang dibedakan menjadi tagihan atas nama (op naam), atas bawa (aan toonder) dan tagihan atas tunjuk (aan order). Hal ini menambah keragaman obyek gadai; Ketiga, larangan janji milik, di mana ditentukan 
bahwa kreditur tidak boleh secara otomatis memiliki benda gadai kalau debitur wanprestasi, segala janji yang bertentangan dengan itu adalah batal demi hukum (Pasal 1154 KUH. Perdata). Hal ini dimaksudkan untuk melindungi debitur dari kemungkinan tindakan penyalahgunaan wewenang oleh kreditur penerima gadai; Keempat, kreditur dapat memohon kepada Hakim untuk menentukan cara lain penjualan benda gadai atau memohon kepada hakim agar pemegang gadai diizinkan untuk membeli sendiri harga yang ditentukan oleh Hakim (Pasal 1156 KUH. Perdata); Kelima, benda gadai bersifat tidak dapat dibagi-bagi, artinya dibayarnya sebagian hutang debitur, tidak dapat dijadikan alasan untuk meminta dibebaskannya sebagian benda gadai dari ikatan jaminan gadai (Pasal $1160 \mathrm{KUH}$. Perdata).

Persamaan yang hakiki antara Rahn dan gadai (Pand), bahwa aturan gadai (pand) dalam $\mathrm{KUH}$. Perdata sudah menjadi ketentuan yang diakui dan dikenal dalam peraturan hukum jaminan secara internasional, dengan demikian maka secara logis Rahn berkedudukan sebagai bentuk varian dari gadai (pand). Konsekuensinya adalah bahwa berbagai ketentuan gadai (pand) sebagaimana diatur dalam KUH. Perdata dapat diterapkan guna melengkapi ketentuan hukum Rahn secara analogi.

Salah satu ketentuan dalam gadai menurut KUH. Perdata yang tidak diatur dalam ketentuan Rahn adalah penjaminan benda bergerak tidak bertubuh atau hak tagih yang dapat dibedakan menjadi tagihan atas nama (op naam), tagihan atas bawa (aan tonder) dan tagihan atas tunjuk (aan order). Dengan adanya perkembangan di bidang bisnis atau perekonomian dewasa ini, apalagi menghadapi era globalisasi dituntut adanya pengembangan macam benda yang dapat dijadikan jaminan hutang. Selain itu ketentuan di atas sudah menjadi ketentuan yang diakui dan dikenal dalam peraturan hukum jaminan secara internasional.

Sebagai varian dari gadai (pand) ditunjukkan bahwa Rahn dikenakan biaya administrasi, asuransi, biaya perawatan dan penyimpanan benda gadai (arun) berdasarkan perjanjian sewa (Akad ljarah). Perlu ditegaskan di sini bahwa karakter pemberian pinjaman uang yang dijamin dengan Rahn adalah tidak berdasarkan sistem bunga, melainkan dengan sistem pemungutan biaya pemeliharaan dan penyimpanan benda jaminan dengan cara menentukan prosentase tambahan dari pokok hutang yang diperhitungkan setiap bulan. Praktek di Perum Pegadaian Syariah dalam menentukan besarnya biaya-biaya tersebut dikonstruksikan sebagai perjanjian sewa-menyewa (ijarah) tempat penyimpanan (ma'jur) dengan ketentuan perhitungan besarnya sewa untuk jangka waktu per sepuluh hari kalender dan keseluruhan uang sewa (ijarah) tersebut wajib dibayar sekaligus pada akhir jangka waktu Akad Rahn atau bersama dengan dilunasinya pinjaman.

\section{Kedudukan Rahn dalam Sistematika Hukum Jaminan Indonesia}

Pengaturan mengenai hak jaminan kebendaan merupakan bagian dari Buku II KUH. Perdata yang mengatur tentang benda, berdasarkan suatu pertimbangan bahwa hak kebendaan mempunyai dua sifat yaitu memberikan kenikmatan dan memberikan jaminan. Hak kebendaan yang bersifat memberikan kenikmatan berhubungan dengan sifat benda yaitu untuk dipergunakan, dipakai atau dinikmati; sedangkan hak kebendaan yang bersifat memberikan jaminan berhubungan dengan nilai ekonomis benda yang dapat dijadikan sebagai pendukung nilai (hutang). Hak kebendaan yang bersifat memberikan kenikmatan dapat tertuju atas benda sendiri yaitu hak milik (eigendom) atau tertuju pada benda orang lain seperti : hak pakai hasil (vruchtgebruik), hak guna bangunan (opstal), hak guna usaha (erfpacht), hak pakai dan hak mendiami; sedangkan hak kebendaan yang bersifat memberikan jaminan selalu tertuju pada benda milik orang lain.

Buku II KUH Perdata menurut doktrin bersifat tertutup, dalam arti orang tidak leluasa membuat hak kebendaan baru kecuali yang sudah diatur dalam undang-undang. Penambahan hak kebendaan baru harus dilakukan berdasarkan suatu undang-undang, seperti Fidusia berdasar Undang-Undang Nomor 42 
Tahun 1999, dan Hak Tanggungan berdasarkan Undang-Undang Nomor 4 Tahun 1996.

Hingga saat ini lembaga jaminan kebendaan yang diatur dalam ketentuan perundangundangan terdiri dari : Gadai dan Fidusia untuk penjaminan benda bergerak dan Hipotik serta Hak Tanggungan untuk penjaminan benda tetap. Dengan berlakunya Rahn sebagai bentuk varian dari Gadai (pand), harus disesuaikan dengan sistematika pengaturan hukum jaminan yang ada; sehingga menjadi bagian dari sistem dan tidak terjadi pertentangan di dalam sistem hukum itu sendiri, yaitu Pertama, bahwa Rahn hanya dipakai untuk penjaminan benda-benda bergerak dan tidak untuk penjaminan benda tetap seperti hak atas tanah dan benda tidak bergerak menurut ketentuan undang-undang; Kedua, bahwa Rahn sebagai jaminan kebendaan yang baru, harus diatur dalam bentuk undangundang, berhubung dengan sifat tertutup dari ketentuan hukum mengenai hak kebendaan.

\section{Penutup}

Simpulan

Konstruksi hubungan hukum Rahn (Gadai Syariah) identik (persamaan dalam unsur) dengan konstruksi hubungan hukum gadai (pand) menurut KUH. Perdata, yaitu sebagai perjanjian ikutan (accessoir) terhadap perjanjian pokok yang pada umumnya berupa perjanjian peminjaman sejumlah uang, obyeknya berupa benda bergerak dan benda tersebut harus dikeluarkan dari kekuasaan debitur (asas inbezitstelling), dan memberikan hak kepada kreditur untuk mengambil pelunasan lebih dahulu atas hasil eksekusi benda yang secara khusus diperikatkan. Oleh karena itu dapat dikatakan bahwa Rahn sebagai varian dari ketentuan gadai (pand) dalam KUH. Perdata, sehingga berbagai ketentuan dalam gadai (pand) yang bersifat lebih lengkap dan rinci dapat diterapkan dalam Rahn dengan penerapan secara analogi dalam rangka pembentukan hukumnya. Sedangkan perbedaannya adalah pada transaksi pokok yang dijamin, dimana dalam Rahn merupakan transaksi peminjaman sejumlah uang tanpa bunga, sedangkan dalam gadai (pand) pada umumnya adalah transaksi peminjaman uang dengan disertai bunga. Kedudukan Rahn dalam sistematika hukum jaminan nasional adalah sebagai salah satu sub sistem yang mengatur tentang lembaga jaminan benda bergerak.

\section{Saran}

Rahn harus segera diatur dalam suatu undang-undang untuk memberikan dasar hukum sebagai lembaga jaminan kebendaan, dan menjadi sub sistem hukum jaminan nasional mengenai penjaminan benda bergerak.

Perlu adanya perluasan obyek benda yang dapat dijadikan jaminan dalam Rahn, meliputi benda bergerak tidak berwujud atau hak tagih, karena hal ini sudah menjadi ketentuan hukum yang berlaku secara internasional. 